\title{
Brazilian legislation for functional foods and the interface with the legislation for other food and medicine classes: contradictions and omissions
}

\section{| ${ }^{1}$ Tatiana Feitoza Vianna da Silveira, ${ }^{2}$ Cid Manso de Mello Vianna,}

\section{${ }^{3}$ Gabriela Bittencourt Gonzalez Mosegui |}

Abstract: Functional foods are generally defined as foods that, due to their physiologically active substances, benefit health in addition to providing basic nourishment. As Brazilian legislation does not provide a definition for functional foods, the only possible actions is to claim that some foods have functional health proprieties. Based on a review of legislation, this paper discusses not only the lack of transparency in relation to the categories of products classified as foods and medicinal plants, but also the interactions and contradictions of functional food product legislation. Products may be classified either within the "New Food /or Ingredient category" or as "Bioactive Substances or Isolated Probiotics with Functional Properties and/ or Health Claims". Products such as garlic can also be classified into multiple food categories and as medicinal plants. Intersections in food legislation, especially with respect to functional and new food products, lead to misunderstandings and even omissions on the part of Brazilian National Sanitary Surveillance Agency (ANVISA). Moreover, health claims on food product labels can make distinction between foods and medicines difficult for consumers. In Brazil, clearer rules for the industry are necessary so that the consumer is not deceived by false cure promises.

Palavras-chave: Functional Food, Legislation, Health.

\author{
1 Mestranda em Saúde Coletiva \\ Departamento de Planejamento \\ e Administração em Saúde do \\ IMS-UERJ. Endereço eletrônico: \\ tatianafeitoza@uol.com.br \\ ${ }^{2}$ Doutor em Economia da \\ Indústria e da Tecnologia \\ (UFRJ), professor adjunto no \\ Departamento de Planejamento \\ e Administração em Saúde do \\ IMS-UERJ \\ ${ }^{3}$ Doutora em Saúde Coletiva \\ (IMS-UERJ), professora \\ visitante no Departamento de \\ Planejamento e Administração \\ em Saúde do IMS-UERJ; \\ professora adjunta no \\ Departamento de Saúde e \\ Sociedade, Universidade \\ Federal Fluminense.
}




\section{Introduction}

The concept of functional foods appeared in Japan in the early 1990s, and describes those foods that, due to their physiologically active components, can benefit people's health and provide basic nourishment (STRINGHETA et al., 2007; ILSI, 1999). The Japanese government, concerned with the growing expense of the population's health care and considering the high life expectancy in that country, supported research on functional foods (NCEFF, 2006). The Health and Welfare Ministry implemented the program Foods for Specified Health Use (FOSHU), in which functional foods are to be developed using natural ingredients, to be part of the diet, and to perform specific functions in the organism such as biological (immunological) defense mechanisms, preventing or treating of diseases/disorders, improving physical, mental or general health conditions, or slowing the aging process (STRINGHETA et al., 2007; ALVÍDREZ-MORALES, et al, 2002).

There is currently no internationally accepted definition for functional foods, although some regulatory agencies and institutes have tried to agree on one. For example, the International Life Sciences Institute of North America (ILSI) defined functional foods as those foods that, due to their physiologically active components, benefit people's health in addition to providing basic nutrition (ILSI, 1999). The Food Directorate of Health, Canada, adopted the following definition: "Functional food is the one similar to a conventional food or the conventional food itself, consumed as part of the usual diet, with proved ability to promote physiological benefits and/or to reduce the risks of chronic diseases, beyond performing the basic nutritional functions" (NCEFF, 2006).

Brazilian legislation does not provide a definition of functional foods, but it is possible to claim that certain foods have functional health properties. A food item can claim to be a "Food with Functional Properties and/or Health Claims", acknowledged by the Brazilian National Sanitary Surveillance Agency (ANVISA), although it may not be classified as a functional food (STRINGUETA et al., 2007). Consequently, there is significant conflict between food and medicinal plants legislation.

This was a descriptive study based on data collected from documents, reports, ordinances and resolutions from the Brazilian Ministry of Health. Documents 
used in the comparison were from 1999 to 2009. This paper is divided into three sections: the first discusses Brazilian legislation regarding foods with functional properties and/or health claims and the lack of comprehensibility in the classification of products as either foods or medicinal plants; the second presents the interactions and contradictions within Brazilian legislation; in the last section, final remarks are presented.

\section{Brazilian legislation on functional foods}

In Brazil, it is possible to declare some foods as having functional and/or health properties since ANVISA developed legislation that defines "Food Functional Properties and/or Health Claims". In this sense, the Functional Property Claim of a food product is defined as a claim "concerning the metabolic or physiological role that the nutrient or non-nutrient has in growth, development, maintenance and/or other normal functions of the human organism" (BRAZIL, 1999 b). This attribute must appear on the food label in a sentence such as "Food fibers help bowels work well. Intake must be associated with a balanced diet and healthy habits" (BRAZIL, 2006 b).

Functional properties and/or health claims on a food label are tools that allow the consumer to know the possible benefits the food can offer. Generally speaking, information on the benefits inherent to foods and nutrition, when described on labels, helps consumers select a healthy diet (WHO, 2004).

On January 13, 1998, the decree SVS/MS 31 was issued. It was a technical rule for food supplemented with essential nutrients that legally defined a nutrient as "any substance generally consumed as food constituent that provides energy or is necessary for the growth, development and health maintenance; or whose absence brings biochemical and physiological changes in the organism" (BRAZIL, 1998). Although the concept of a nutrient was thus made clear, the concept of a non-nutrient has not yet been established by Brazilian legislation.

It is reasonable that, for a product to be classified as food, it must comply with decree 986/69, which defines food as "any or mixed substances designed to offer the regular elements for the formation, maintenance and development of the human organism (BRAZIL, 1969). In 1999, ANVISA created a new 
category known as "new food products" (BRAZIL, 1999 a), defined as "food or substances not previously consumed in the country, or food with already consumed substances that can be added or used in higher levels as compared to food used in regular diets" (BRAZIL, 1999 a).

ANVISA issued RDC resolution 2/2002 on January 7, 2002, which approved the Technical Rules for Bioactive and Isolated Probiotic Substances with Functional Properties or Health Claims. Therein, probiotics were defined as live microorganisms able to improve the microbial balance of the bowels, resulting in beneficial effects on people's health; bioactive substances were defined as non-nutrients that have specific metabolic or physiological actions (SAAD, 2006; BRAZIL, 2002). After this resolution, Brazilian legislation recognized two food categories with functional properties and/or health claims. The first includes food items with functional properties and/or health claims, and the second includes bioactive substances and isolated probiotics with functional properties and/or health claims.

An analysis of ANVISA's records shows that the same product can be classified into different food categories, i.e., it can be classified as a New Food or Ingredient and as a Bioactive Substance or Isolated Probiotic with Functional Properties and/or health claims. What makes this classification different, in a preliminary analysis, is that the only isolated probiotic is grant to have potential for functional properties and/or health claims.

Another situation that demands more attention is the possible classification of the same product, for example garlic and guarana, into distinct food categories and as medicinal plants. Thus, the intersections in food legislation, especially "functional food products" and "new food products" lead to misunderstandings and even omissions on the part of ANVISA.

\section{Interactions and contradictions in Brazilian legislation}

Brazilian legislation allows for inconsistencies and important interactions not only within food legislation, but, more troublingly, between food and medical legislations. The following table shows interactions resulting from classification of the same product into different categories. 


\begin{tabular}{|l|l|}
\hline Product & Possible classification \\
\hline Chitosan & $\begin{array}{l}\text { Food with functional property and/or health claim (Brazil, 2004a) } \\
\text { New food or ingredient (Brazil, 2001a) }\end{array}$ \\
\hline Lycopen & $\begin{array}{l}\text { Bioactive substance or probiotic with functional property and/or } \\
\text { health claim (Brazil, 2006b) } \\
\text { Food with functional property and/or health claim, (Brazil, 2004b) } \\
\text { New food or ingredient (Brazil, 2001b) }\end{array}$ \\
\hline Garlic & $\begin{array}{l}\text { New food or ingredient (Brazil, 2006a) } \\
\text { Medicinal plant (Brazil, 2005a) }\end{array}$ \\
\hline
\end{tabular}

Based on Silveira (2006).

The following examples show situations that demonstrate inconsistencies and omissions on the part of ANVISA.

\section{Chitosan caplets}

The register license of Chitosan is an example of the lack of transparency in the distinction between medicinal plants and foods with functional properties and/or health claims. In this case, the product is marketed in pharmaceutical forms and is not regularly consumed as a food. It is indicated as a complement or adjuvant in weight reduction regimen. Its alleged effects, indications and posology are similar to those presented by medicines, and advertising in written and spoken media reinforces the idea that it is a medicinal plant.

The claim approved by ANVISA states that "chitosan helps reducing fat and cholesterol absorption. Its use must be associated with balanced diet and healthy habits" (ANVISA, 2006). Chitosan, usually found in some types of fungi, is often obtained by deacetylation of chitin, a polysaccharide that is highly abundant in nature and that forms the outer skeletons of insects and crustaceans (DIAS et al., 2008; KLUG et al., 1998). This means that chitosan is obtained via laboratory methods, i.e., it is not found in nature or formed in the human organism. 
Analysis of the classification of the product "chitosan" also indicates some controversy. According to ANVISA, for this product to be classified as a functional food, its traditional use should be proved through observation of a population (BRAZIL, 1999 b). However, Brazilians do not consume crustacean carapaces, and even if they did, they would not ingest chitosan, but chitin.

By definition, food must provide the human organism with the normal elements for its formation, maintenance and development (BRAZIL, 1969), which does not occur in this case. Although there are no medical claims in Brazilian legislation, the claim approved by ANVISA for this food product classifies it as an anti-lipemic medicine. The idea of food intake improving muscular mass or body weight is widely accepted. However, the concept of food caplets that reduce fat and cholesterol absorption is confusing.

\section{Lycopen}

The main sources of lycopen in the human diet are tomato (Lycopersicon esculentum Mill.) and tomato products such as juices, soups, sauces and ketchup (CARVALHO et al., 2005). The lycopen pigment (C40H56) belongs to the subgroup of non-oxygenated carotenoids characterized by an acyclic and symmetric structure containing 11 double-bonds. Due to its chemical structure, lycopen is one of the best suppressors of biological free radicals. Of several carotenoids evaluated, lycopen was one of the most efficient anti-oxidants, and can donate electrons to neutralize singlet oxygen molecules and other oxidant molecules before they damage cells (AGRAWAL; RAO, 2000).

There is evidence that intake of tomato and its products is associated with a reduced risk of cancer and cardio-vascular diseases, while protecting lipids, low-density lipoproteins (LDL), proteins and deoxyribonucleic acids (DNA) (SHAMI, MOREIRA, 2004; AGARWAL, RAO, 2000). Lycopen intake is also inversely associated with the risk of heart attack. Oxidation of LDL molecules is the first step in the development of atherogenic processes and consequent coronary disease (GIOVANNUCCi et al., 1995; POOL - ZOBEL et al., 1997; AGARWAL, RAO, 2000; WILLIS; WIANS, 2003).

Tomato is defined as food as it provides the human organism with normal elements (e.g., carbohydrates, proteins, vitamins and minerals) for its formation, maintenance and development (EMBRAPA, 2006). On the other hand, lycopen 
does not meet the requirements of decree 986/69 concerning the definition of food, nor can it be defined as a nutrient because it does not provide energy and is not useful for growth, development and life maintenance, and moreover its absence does not lead to chemical or physiological alterations. As an alternative, lycopen can be included in the non-nutrient category. Perhaps one can consider lycopen a "non-nutrient with specific metabolic or physiologic action" (BRAZIL, 2002). However, if it is a non-nutrient with specific metabolic functions, lycopen should be characterized as a medicine.

Thus, as lycopen is classified in the category of "Bioactive Substances and Isolated Probiotics with Functional Properties and/or Health Claims", consumers can find on product label the following claim: "Lycopen has antioxidant action that protects cells against free radicals. Its consumption must be associated with a balanced diet and healthy habits" (ANVISA, 2006). However when lycopen is considered under New Food categorie only the daily portion to be taken is indicated.

This leads to an obvious question: what is the use of a food product that does not satiate hunger and is not intended to aid in the formation, maintenance and development of an organism?

\section{Garlic}

Garlic is another example of the numerous possible classifications of food products and medicinal plants. As a food, garlic caplets or garlic oil caplets can be included into the category of "new foods and/or ingredients," but they can be included in the medicinal plant category as well.

To be classified as a medicinal plant, a product must comply with requirements such as the following:

- A descriptive report must be available on drying, stabilization (if required) and conservation methods, with appropriate controls, whenever necessary.

- The part of the plant that is used and the solvents, excipients and/or means used to extract the product must be available. This information must be followed by an analysis report issued by the supplier.

- Authenticity tests are required (organoleptic characterization, macroscopic and microscopic identification). 
- Pureness and integrity tests are required, including ashes, insoluble ashes in chloridric acid, humidity, and detection of odd matter, microbiological agents and heavy metals contaminants. If methods to eliminate contaminants are used, the methods and studies of resulting alterations in the raw material are required.

- Qualitative and quantitative analyses of the active principles and/or markers (when these are known) and chemical compound classes of the species are required, as well as quality control of the finished product. (BRAZIL, 2004c).

Because the classification of the product "garlic" into any potential food category is not connected to any of the above requirements (ANVISA, 2008), the consumer can use it indiscriminately. In this case there is no restricted use apart from usage recommendations issued by the supplier (BRAZIL, 1999 a).

If garlic is classified as a medicine, there must be mention, as stated above, of indications, therapeutic actions, dose, administration route, posology and restrictions. It must also be pointed out that garlic is culturally consumed in large quantities, in different forms, by the Brazilian population (SEAPA, 2008).

\section{Final remarks}

In general, regulatory agencies believe that nutritional information can serve as an efficient way for health consumers to choose more healthy food. They also acknowledge that labels can be confusing if they are designed to allow consumers to understand them immediately (WHO, 2004). Moreover, these potential misunderstandings may conflict with the Consumer's Defense Code (CDC), established by Act 8078, dated September 11, 1990 and ruled by Decree 2181/1997. After all, according to article 6, item III of this Code, the consumer has the right to "adequate and clear information on the different products and services, with the correct specification of quantity, characteristics, composition, quality and price, as well as their risks".

The fourth item of the same article states that the consumer has the right to "protection against deceiving and abusive advertising, coercitive unfair market methods, and abusive or compulsory practices and clauses in the provision of products and services". It must be emphasized that the CDC, in its fourth chapter, section I, article VIII, clearly mentions health protection and consumer safety, and this aspect requires more attention from legislation related to foods 
with functional properties and/or health claims and other foods and medicine classes existing in Brazil.

Functional foods and health claims are some of the most controversial and complex topics in the current debate among international regulatory agencies (LAWRENCE \& RAYNER, 1998). This is due to the fact that these foods can reduce health care expenses, as health claims on food labels can be an important tool for nutritional education, providing information on health benefits that some food products can bring. Still, according to these authors, health claims on food labels can become a dangerous tool that allows industry, through labeling and marketing, to make it difficult for consumers to distinguish between foods and medicines.

In Brazil, in the late 1990s, a legal structure was created in the field of food products. In only three years, there rules were created establishing a dozen new food categories. Still, there is a "dark zone" of knowledge, i.e., significant gaps that allow for classification of the same product both as a food and as a medicine. The absence of unclear criteria, the omission of important definitions such as a "functional food" and the lack of a clear distinction between ingredients and non-ingredients are central issues underlying the existence of these gaps (SILVEIRA, 2006).

ANVISA's Resolution n. 19, dated April 30, 1999, which approved the Technical Rule for Product Registration of Foods with Functional Properties and/or Health Claims on Label", recommended a review two years after it came to force, but ten years have passed and no review has been conducted (BRAZIL, 1999c).

Health claims should not be avoided as they can be an important means to keep consumers informed. However, clear rules must be established so that consumers can have access to a real health maintenance (SILVEIRA, 2006).

One important omission is that, although all claims should include the sentence "intake must be associated with a balanced diet and health habits", no legislation explains what "health habits" are. Regulatory agencies in all countries must ensure that consumers have safe and quality food products. Brazil needs clearer rules for industry so that the CDC is obeyed and consumers will not be deceived by false cure promises.

Finally, this paper does not aim to discuss food functionality. We focused on discussing the public health risks related to the absence of clear definitions 
in this emergent food category There are several questions regarding the lack of clear definitions on the part of ANVISA, such as those related to the lack of a definition of non-nutrients, the definition of the percentage of an active component required for a food to make a functional or health claim, and whether, if a defined active component exists within a substance, the substance should no longer be considered a food product, but rather a medicine.

According to Brazilian legislation, food is not intended to prevent, treat or cure any disease (BRAZIL, 1969). In not defining what a functional food or a non-nutrient is, the Brazilian government gives rise to several doubts, mistakes and omissions.

\section{References}

AGARWAL, S.; RAO, A.V. Tomato lycopene and its role in human health and chronic diseases. Canad Med Assoc J., v. 163, n. 6, p. 739-44, 2000.

AGÊNCIA NACIONAL DE VIGILÂNCIA SANITÁRIA (Brazil). Alimentos com Alegações de Propriedades Funcionais e ou de Saúde, Novos Alimentos/Ingredientes, Substâncias Bioativas e Probióticos VIII - Lista das Alegaçōes Aprovadas. 2006. Available on: < http:// www.anvisa.gov.br/alimentos/comissoes/tecno_lista_alega.htm> Access on: Mach 3, 2006.

Alimentos com Alegaçōes de Propriedades Funcionais e ou de Saúde, Novos Alimentos/Ingredientes, Substâncias Bioativas e Probióticos VIII - Lista dos Novos Alimentos aprovados. 2008. Available on: http://www.anvisa.gov.br/alimentos/comissoes/novos_alimentos.htm. Access on: July 19, 2008.

ALVÍDREZ-MORALES. et al. Tendencias en la producción de alimentos: alimentos funcionales. Revista Salud Pública y Nutrición. v. 3, n.3, 2002.

BRAZIL. Decreto-Lei n.o 986, October 12, 1969. Institui normas básicas sobre alimentos. Diário Oficial da Uniāo, Brasília, October 21, 1969. Portaria $n^{\circ}$. 31, January 13, 1998. Aprova o Regulamento Técnico referente a Alimentos Adicionados de Nutrientes Essenciais, constante do anexo desta Portaria. Diário Oficial da União; Poder Executivo, January 16, 1998. SVS/MS - Ministério da Saúde. Secretaria de Vigilância Sanitária.

Resolução no. 16, April 30, 1999 a. Aprova o Regulamento Técnico de Procedimentos para registro de Alimentos e ou Novos Ingredientes, constante do anexo desta Portaria. Diário Oficial da União; Poder Executivo, December 3, 1999.

Resolução $n^{\circ} .18$, de 30 de abril de 1999 b. Aprova o Regulamento Técnico que estabelece as diretrizes básicas para análise e comprovação de propriedades funcionais e ou de saúde alegadas em rotulagem de alimentos, constante do anexo desta portaria. Diário Ofcial da Uniāo; Poder Executivo, de 03 de maio de 1999. 
Resolução no. 19, April 30, 1999 c . Regulamento Técnico para Procedimento de

Registro de Alimentos com Alegaçōes de Propriedades Funcionais e ou de Saúde em Sua Rotulagem. Diário Oficial da União; Poder Executivo, May 3, 1999.

Resolução RE no. 38, de February 21, 2001 a. Concede registro de alimento, aditivo e produto importado. Diário Oficial da Uniāo; Poder Executivo, February 22, 2001.

Resolução RE no. 148, July 18, 2001 b. Concede o registro de alimento, registro de aditivo, registro de produto importado, modificação de formula do produto, inclusão de marca, retificação de publicação de registro. Diário Oficial da União; Poder Executivo, de 19 de julho de 2001.

Resolução RDC nº. 2, de January 7, 2002. Aprova o Regulamento Técnico de Substâncias Bioativas e Probióticos Isolados com Alegação de Propriedades Funcional e ou de Saúde. Diário Oficial da Uniāo; Poder Executivo, de 09 de janeiro de 2002.

Resolução RE no. 1, January 8, 2004 a. Concede o registro de alimentos e bebidas, registro de alimentos e bebidas importado, registro único de alimentos e bebidas, retificação de publicação de registro, recurso interposto deferido. Diário Oficial da Uniāo; Poder Executivo, January 9, 2004.

Resolução RE no. 23, February 3, 2004 b. Concede o registro de alimentos e bebidas, registro único de alimentos e bebidas, registro de alimentos e bebidas -importado. Diário Oficial da União; Poder Executivo, de 04 de fevereiro de 2004.

Resolução RDC no. 48, March 16, 2004 c. Dispõe sobre o registro de medicamentos fitoterápicos. Diário Oficial da União; Poder Executivo, March 18, 2004.

Resolução RE no. 1891, July 29, 2005 a. Concede o Registro de Medicamento Similar, Cancelamento de Registro do Medicamento a Pedido, Renovação de Registro de Medicamento Similar, Inclusão de Nova Apresentação Comercial - Produto Fitoterápico, Alteração de Excipiente, Inclusão de Nova Apresentação Comercial, Registro de Medicamento Especifico, Alteração de Local de Fabricação, Recurso Administrativo por Reconsideração de Indeferimento, Renovação de Registro de Medicamento Especifico, Inclusão de Novo Acondicionamento, Registro de Fitoterápico, de Produtos farmacêuticos. Diário Oficial da União; Poder Executivo, August 1 1 2005.

Resolução RE nº. 2475, de 03 de outubro de 2005 b. Concede a Inclusão de Nova Apresentação Comercial, Retificação de Publicação de Registro, Alteração do Nome Comercial do Medicamento, Cancelamento de Registro do Medicamento a Pedido, Cancelamento de Registro da Apresentação do Medicamento a Pedido, Alteração de Excipiente, Renovação de Registro de Medicamento Similar, Inclusão de Novo Acondicionamento, Alteração de Local de Fabrico, Registro de Medicamento Especifico, Registro de Produto Biológico, Renovação de Registro de Medicamento Especifico, Alteração do Prazo de Validade, Registro de Produto Biológico, Alteração de Produção do Medicamento, Caducidade de Registro de Medicamento, 
Renovação de Registro - Produto Biológico, Renovação de Registro de Medicamento Fitoterápico, Alteração de Local de Fabricação, Renovação de Registro de Medicamento Novo, Renovação de Registro de Medicamento Homeopático, Registro de Medicamento Similar, de Produtos farmacêuticos. Diário Oficial da União; Poder Executivo, October $4^{\text {th }}, 2005$.

Resolução RE no. 569, de 22 de fevereiro de 2006 a. Concede a revalidação de registro, registro de alimentos e bebidas, inclusão de marca, retificação de publicação de registro, recurso interposto deferido, alteração rotulagem, alteração de fórmula do produto, registro de aditivo e coadjuvante de tecnologia-importado. Diário Oficial da União; Poder Executivo, February 24, 2006.

Resolução RE no. 1452, de 12 de maio de 2006 b. Conceder Registro de Alimentos e Bebidas, Registro Único de Alimentos e Bebidas, Extensão para Registro Único, Inclusão de Marca, Alteração de Fórmula do Produto, Alteração de Rotulagem, Alteração do Nome/ Designação do Produto e Atendimento ao Regulamento Técnico de Procedimentos para Registro de Alimentos com Alegação de Propriedades Funcionais e ou de Saúde, para produtos registrados que passam a utilizar alegação(ões) na rotulagem na conformidade da relação anexa. Diário Oficial da União; Poder Executivo, May 15, 2006.

CARVALHO, W.; FONSECA, M.E.N.; SILVA, H.R.; BOITEUX, L.S.; GIORDANO, L.B. Estimativa indireta de teores de licopeno em frutos de genótipos de tomateiro via análise colorimétrica. Horticultura Brazileira, Brasília, v.232 n.3, p.819-825, July-Sept 2005.

DIAS, F.S. et al. Um sistema simples para preparação de microesferas de quitosana. Quím. Nova, v.31 n.1 São Paulo, 2008. Available on: <http://www.scielo.br/scielo.php?script=sci_ arttext\&pid=S0100-40422008000100028\&lng=pt\&nrm=isso >. Ac on: 14 August 2008.

EMPRESA BRAZILEIRA DE PESQUISA AGROPECUÁRIA - EMBRAPA. (Brazil). Cultivo de tomate para industrialização, Composição química do fruto. Available on: < http:// sistemasdeproducao.cnptia.embrapa.br/FontesHTML/Tomate/TomateIndustrial/composicao.htm\#tabela1> Access on: 2 February 2006.

GIOVANNUCCI, E.; ASCHERIO, A.; RIMM, E.; STAMPFER, M.; COLDITZ, G.; WILLETT, W. Intake of carotenoids and retinol in relation to risk of prostate cancer. $J$ Natl Cancer Inst., v. 87, n. 3. p. 1767-76, 1995.

INTERNATIONAL LIFE SCIENCES INSTITUTE - ILSI. Safety assessment and potential health benefits of food components based on selected scientific criteria. ILSI North America Technical Committee on Food Components for Health Promotion. Crit Rev Food Sci Nutr., v. 39, p. 203-316, 1999.

KLUG, M.; SANCHES, M.; LARANJEIRA, M. et al. Analysis of adsorption isotherms of $\mathrm{Cu}(\mathrm{II}), \mathrm{Ni}(\mathrm{II}), \mathrm{Pb}(\mathrm{II})$ and $\mathrm{Zn}$ (II) by $\mathrm{N}$-(3,4-dihydroxybenzyl) chitosan using nonlinear regression method. Quim. Nova, v. 21, n. 4, p. 410-413. July/Aug. 1998. 
LAWRENCE, M.; RAYNER, M. Functional foods and health claims: a public health policy perspective. Public Health Nutr. V.1, n.2, p.75-82, jun. 1998.

NATIONAL CENTER OF EXCELLENCE IN FUNCTIONAL FOODS. HEALTH CLAIMS REGULATORY SYSTEMS. (NCEFF) 2006. Available on: < http://www.nceff.com.au/pdf/Canada.pdfhttp://www.nceff.com.au/pdf/Canada.pdf > Access on: 21 March 2006.

POOL-ZOBEL, B.; BUB, A.; MÜLLER, H.; WOLLOWSKI, I. R. Consumption of vegetables reduces genetic damage in humans: first results of a human intervention trial with carotenoid-rich foods. Carcinogenesis, v. 18, n. 9, p. 1847-50, 1997.

RAO, A.V.; AGARWAL, S. Role of antioxidant lycopene in cancer and heart disease. J Am Coll Nutr. v.19, n. 5, p. 563-9, oct. 2000.

SAAD, S.M.I. Probióticos e prebióticos: o estado da arte. Revista Brasileira de Ciências Farmacêuticas, vol. 42, n. 1, jan./mar., p., 1-16, 2006.

SHAMI, N.J.I.E.; MOREIRA, E.A.M. Licopeno como agente antioxidante. Rev. Nutr., Campinas, 17(2):227-236, abr./jun., P. 227-236, 2004. Available on: <http://www.scielo. br/pdf/rn/v17n2/21135.pdf.> Access on: 14 August 2008.

SILVEIRA, T.F.V. da. Uma análise de legislaçôes para alegaçôes de propriedade funcional e saúde: alimentos ou medicamentos? $89 \mathrm{f}$. Dissertação (Mestrado em Saúde Coletiva) - Instituto de Medicina Social, Universidade do Estado do Rio de Janeiro, Rio de Janeiro. 2006.

STRINGHETA, P.C. et al. Políticas de saúde e alegações de propriedades funcionais e de saúde para alimentos no Brazil. Revista Brazileira de Ciências Farmacêuticas. vol. 43, n. 2, abr./jun.: 181-194, 2007.

SECRETARIA DE ESTADO DE AGRICULTURA, PECUÁRIA E ABASTECIMENTO. SUPERINTENDÊNCIA DE POLITICA E ECONOMIA AGRÍCOLA (SEAPA) . Available on: <www.agricultura.mg.gov.br/dados/alho.pdf.> Access on: 19 August 2008.

WILLIS, M.S.; WIANS, J.R. The role of nutrition in preventing prostate cancer: a review of the proposed mechanism of action of various dietary substances. Clin Chim Acta, v. 330, p.57-83, 2003.

WHO. WORLD HEALTH ORGANIZATION. Hawkes, Corinna. Nutrition labels and health claims: the global regulatory environment. 2004. Available on: < whqlibdoc.who.int/ publications/2004/9241591714.pdf > Access on 2 July 2005. 
A legislação brasileira de alimentos funcionais e a interface com a legislação de outras classes de alimentos e medicamentos: um caso de contradiçōes e omissóes

Alimentos funcionais são aqueles que, por seus componentes fisiologicamente ativos, beneficiam à saúde além da nutrição básica. A legislação Brasileira não contempla definição sobre Alimentos Funcionais, possibilitando apenas alegar que determinados alimentos possuem propriedades funcionais e/ou de saúde. Com base na revisão da legislação, apresenta-se uma discussão sobre sua ausência de clareza a respeito da categorização dos produtos que são registrados como alimentos e como medicamentos fitoterápicos; assim como interaçôes e contradições da legislação de alimentos funcionais. Assim, um produto pode ser registrado tanto nas categorias de Novos Alimentos e Ingredientes como de Substâncias Bioativas e Probióticos Isolados com Alegação de Propriedades Funcional e/ou de Saúde. Há também possibilidade de registro de um produto como o alho, em diferentes categorias de alimentos e medicamentos fitoterápicos. As interseções existentes na legislação de alimentos, especialmente a de "Alimentos Funcionais" e "Novos Alimentos", sugerem confusão e até mesmo omissão por parte da ANVISA. Além disso, as reivindicaçôes da saúde em rótulos de alimentos podem dificultar a distinção entre o alimento e os medicamentos por parte dos consumidores. No Brasil, serão necessárias regras mais claras para a indústria, para que o consumidor não seja ludibriado com falsas expectativas de ganho de saúde.

> Key words: alimentos funcionais, legislação sanitária. 